Acta vet. scand. $1981,22,449-458$.

From the Department of Pathology, Veterinary College of Norway, Oslo.

\title{
AN ENZYME HISTOCHEMICAL INVESTIGATION OF THE INTESTINAL MUCOSA IN DIARRHEIC CALVES*
}

\author{
By \\ Thor Landsverk
}

\begin{abstract}
LANDSVERK, T.: An enzyme histochemical investigation of the intestinal mucosa in diarrheic calves. Acta vet. scand. 1981, 22, 449458. - Selected enzymes were examined in the small intestine of twelve $2-5$ week-old calves, 8 with diarrhea and 4 convalescents. The diarrheic calves showed a reduction of enzyme reactions mainly in the duodenum and middle small intestine, and the crypt reactions appeared most severely affected. In the duodenum, villous alkaline phosphatase, adenosine triphosphate-(ATP)-splitting enzyme, and $\beta$-Dgalactosidase were reduced in 3 calves; the reaction in the corresponding crypts was decreased in 6 calves for the ATP-splitting enzyme and in 4 calves for the $\beta$-D-galactosidase. Six calves showed decrease of villous brush border acid phosphatase, and 3 of villous non-specific esterase. In the middle jejunum, villous ATP-splitting enzyme was reduced in 3 calves, while 5 showed decrease of the corresponding crypt reaction. Convalescents had no enzyme reduction in the duodenum, whereas 1 showed marked reduction of the ATPsplitting enzyme and aminopeptidase in the middle and posterior jejunum. The decreased enzyme reactions in the present material may be caused by immaturity of epithelial cells associated with regenerative crypt hyperplasia and/or microbial destruction of enzymes.
\end{abstract}

enzyme histochemistry; small intestine; villous atrophy; diarrhea; calves.

Diarrhea has been associated with a range of structural and functional changes in the intestinal mucosa. Enzyme studies have given important insights into the pathogenetic mechanisms operating during different forms of diarrhea (Lojda 1974). In calves with certain diarrheic conditions biochemical studies have revealed a decrease in the activity of lactase and phosphatases (Bywater \& Penhale 1969, Abel et al. 1972, Benz \& Ernst 1976,

* This study was supported by grants from the Agricultural Research Council of Norway. 
T a b l e 1. Average regional enzyme reaction detected histochemically in the small intestinal epithelial cells, average ratios of villous length to crypt depth (v:c), and clinical status of the calves.

\begin{tabular}{|c|c|c|c|c|c|c|c|}
\hline \multirow{2}{*}{\multicolumn{2}{|c|}{$\begin{array}{l}\text { Diet } \\
\text { Calf No. }\end{array}$}} & \multicolumn{6}{|c|}{ B1 } \\
\hline & & 1 & 2 & 3 & 4 & 5 & 6 \\
\hline \multicolumn{8}{|c|}{ Duodenum (d2) } \\
\hline ALP & Villus & $+^{\star}$ & $+t+$ & ++ & ++ & $+t+$ & $++t$ \\
\hline $\begin{array}{l}\text { ATP- } \\
\text { s.e. }\end{array}$ & $\begin{array}{l}\text { Villus } \\
\text { Crypt }\end{array}$ & $\begin{array}{l}++ \\
0 /+\end{array}$ & $\begin{array}{l}+++ \\
0 /++\end{array}$ & $\begin{array}{c}+++ \\
+1+++\end{array}$ & $\begin{array}{l}+ \\
0 /+\end{array}$ & $\begin{array}{c}++ \\
+1+++\end{array}$ & $\begin{array}{c}+++ \\
+1+++\end{array}$ \\
\hline ACP & $\begin{array}{l}\text { Villus BB } \\
\text { Villus Cy }\end{array}$ & $\begin{array}{c}+ \\
++\end{array}$ & $\begin{array}{l}++ \\
++\end{array}$ & $\begin{array}{c}+ \\
++t\end{array}$ & $\begin{array}{c}t \\
+t+\end{array}$ & $\begin{array}{r}++ \\
++\end{array}$ & $\begin{array}{r}++ \\
++\end{array}$ \\
\hline$\beta$-D-gal & $\begin{array}{l}\text { Villus } \\
\text { Crypt }\end{array}$ & $\begin{array}{l}++ \\
0 /+\end{array}$ & $\begin{array}{l}+++ \\
0 /++\end{array}$ & $\begin{array}{c}+++ \\
0 /+\end{array}$ & $\begin{array}{l}++ \\
0 /+\end{array}$ & $\begin{array}{l}+++ \\
0 /++\end{array}$ & $\begin{array}{l}+++ \\
0 /++\end{array}$ \\
\hline NSE & Villus & + & $+t+$ & +++ & + & $+t+$ & +++ \\
\hline & $\mathbf{v}: \mathbf{c}$ & 1.1 & 2.8 & 1.1 & 0.7 & 1.7 & 1.8 \\
\hline \multicolumn{8}{|c|}{ Middle jejunum } \\
\hline $\begin{array}{l}\text { ATP- } \\
\text { s.e. }\end{array}$ & $\begin{array}{l}\text { Villus } \\
\text { Crypt }\end{array}$ & $\begin{array}{l}+++ \\
+1++\end{array}$ & $\begin{array}{l}++ \\
0 /+\end{array}$ & $\begin{array}{l}+++ \\
+1++\end{array}$ & $\begin{array}{r}+t+ \\
0 /+\end{array}$ & $\begin{array}{l}+++ \\
0 /++\end{array}$ & $\begin{array}{l}+++ \\
+1++\end{array}$ \\
\hline & $\mathrm{v}: \mathrm{c}$ & 1.1 & 1.5 & 2.0 & 1.3 & 1.3 & 2.4 \\
\hline \multicolumn{8}{|c|}{ Posterior jejunum (pj3)/ileum } \\
\hline $\begin{array}{l}\text { ATP- } \\
\text { s.e. }\end{array}$ & Villus & +++ & + & $+++1++$ & +++ & $++t$ & +++ \\
\hline \multirow[t]{2}{*}{ Am } & Villus & +++ & $+++1+$ & $+++1+$ & +++ & +++ & +++ \\
\hline & $\mathrm{v}: \mathrm{c}(\mathrm{pj} 3)$ & 1.4 & 1.0 & 0.6 & 0.8 & 1.5 & 1.3 \\
\hline \multicolumn{2}{|c|}{ Clinical status } & $\mathbf{D}$ & $\mathbf{D}$ & $\mathbf{D}$ & $\mathbf{D}$ & $\mathbf{C}$ & $\mathbf{C}$ \\
\hline
\end{tabular}

$\begin{array}{ll}\text { ALP } & =\text { alkaline phosphatase } \\ \text { ATP s.e. } & =\text { adenosine triphosphate splitting enzyme } \\ \text { ACP } & =\text { acid phosphatase } \\ \beta \text {-D-gal } & =\beta \text {-D-galactosidase } \\ \text { Am } & =\text { aminopeptidase } \\ \text { NSE } & =\text { non-specific esterase } \\ \text { BB } & =\text { epithelial brush border } \\ \text { Cy } & =\text { epithelial supranuclear cytoplasm } \\ \text { D } & =\text { diarrhea } \\ \text { C } & =\text { convalescent } \\ \text { N } & =\text { normal, no diarrhea }\end{array}$


Table 1 (continued).

\begin{tabular}{|c|c|c|c|c|c|c|}
\hline \multirow[b]{2}{*}{7} & \multirow[b]{2}{*}{8} & \multicolumn{2}{|c|}{ B2 } & \multirow[b]{2}{*}{11} & \multirow[b]{2}{*}{12} & \multirow{2}{*}{$\begin{array}{c}\text { Controls (WM) } \\
17-21\end{array}$} \\
\hline & & 9 & 10 & & & \\
\hline+++ & +++ & +++ & +++ & +++ & +++ & $++t$ \\
\hline $\begin{array}{l}+++ \\
+1+t\end{array}$ & $\begin{array}{l}++ \\
0 /+\end{array}$ & $\begin{array}{l}\text { ND } \\
\text { ND }\end{array}$ & $\begin{array}{l}+++ \\
0 /++\end{array}$ & $\begin{array}{c}+++ \\
+/+++\end{array}$ & $\begin{array}{c}+++ \\
+1+++\end{array}$ & $\begin{array}{c}+++ \\
+1+++\end{array}$ \\
\hline $\begin{array}{r}+t \\
+++\end{array}$ & $\begin{array}{l}+ \\
++\end{array}$ & $\begin{array}{l}\text { ND } \\
\text { ND }\end{array}$ & $\begin{array}{r}+++ \\
++\end{array}$ & $\begin{array}{c}++ \\
++\end{array}$ & $\begin{array}{l}+++ \\
+++\end{array}$ & $\begin{array}{c}++ \\
++\end{array}$ \\
\hline $\begin{array}{l}+++ \\
0 /++\end{array}$ & $\begin{array}{l}++ \\
0 /+\end{array}$ & $\begin{array}{l}+++ \\
0 /++\end{array}$ & $\begin{array}{l}+++ \\
0 /++\end{array}$ & $\begin{array}{l}+++ \\
0 /++\end{array}$ & $\begin{array}{l}+++ \\
0 /++\end{array}$ & $\begin{array}{l}+++ \\
0 /++\end{array}$ \\
\hline+++ & ++ & ND & $+t+$ & $+t+$ & +++ & $\frac{t+}{\overline{\mathbf{x}}} \mathrm{s}$ \\
\hline 1.5 & 1.5 & 1.4 & 2.1 & 2.0 & 1.3 & $3.6 \pm 1.0$ \\
\hline $\begin{array}{l}++ \\
0 /+\end{array}$ & $\stackrel{+}{+}$ & $\begin{array}{l}+++ \\
0 /++\end{array}$ & $\begin{array}{l}+++ \\
+1++\end{array}$ & $\begin{array}{l}+++ \\
+1++\end{array}$ & $\begin{array}{l}++ \\
0 /+\end{array}$ & $\begin{array}{c}+++ \\
+/++ \\
\star_{\bar{x}} \quad \mathrm{~s}\end{array}$ \\
\hline 1.5 & 2.6 & 1.5 & 3.0 & 2.1 & 1.6 & $3.6 \pm 0.5$ \\
\hline+++ & +++ & $++t$ & $++t$ & $++t$ & $++1+$ & $+t+$ \\
\hline+++ & +++ & $+t+$ & $++t$ & $++t$ & $++t+t$ & $\begin{array}{l}+t+ \\
\overline{\mathbf{x}} \\
\mathrm{s}\end{array}$ \\
\hline 1.9 & 2.1 & 1.3 & 1.0 & 0.7 & 0.5 & $1.8 \pm 0.3$ \\
\hline D & D & D & D & $\mathbf{C}$ & C & $\mathbf{N}$ \\
\hline * * & $\begin{array}{l}++ \\
\text { react } \\
\text { betw } \\
\text { betwe } \\
\text { Measi } \\
19,2 \\
\text { for sa } \\
\text { (that } \\
\text { calve }\end{array}$ & $\begin{array}{l}=\text { stror } \\
\text { on; ND } \\
\text { en the be } \\
\text { en two se } \\
\text { rements } \\
\text { are con } \\
\text { nples col } \\
\text { was the } \\
1-12) .\end{array}$ & $\begin{array}{l}g ;++= \\
=\text { not do } \\
\text { sal and } t \\
\text { gments }( \\
\text { rom post } \\
\text { idered } t \\
\text { ected rar } \\
\text { ase for } t\end{array}$ & $\begin{array}{l}\text { moderate; } \\
\text { e; / = var } \\
\text { e apical po } \\
3 \text { and ileun } \\
\text { ior jejunum } \\
\text { represent } t \\
\text { omly in the } \\
\text { samples fr }\end{array}$ & $\begin{array}{l}+=\text { weak; } \\
\text { ation of the } \\
\text { tion of the cr } \\
\text {. } \\
1 \text { (pj1) for c } \\
\text { e lower norm } \\
\text { middle small } \\
\text { m middle jej }\end{array}$ & $\begin{array}{l}0=\text { no } \\
\text { reaction } \\
\text { ypts, or } \\
\text { lves 18, } \\
\text { al limit } \\
\text { intestine } \\
\text { anum of }\end{array}$ \\
\hline
\end{tabular}


Halpin \& Caple 1976). An enzyme histochemical investigation of calf viral enteritis revealed a decrease of the adenosine triphosphatase reaction in calf ileum ( $\mathrm{Abel}$ et al.). In a previous paper pathomorphologic findings in spontaneous calf diarrhea were described (Landsverk 1981a). This study describes the histochemical distribution of enzymes in the small intestine of the diarrheic calves and discusses the significance of the findings with reference to the possible pathogenetic mechanisms implicated in the disease.

\section{MATERIAL AND METHODS}

The material comprises 8 diarrheic calves $(1-4,7-10)$ and 4 convalescent calves $(5,6,11,12)$ also used in other studies (Landsverk 1981a, b, Landsverk et al. in prep.). The calves were given milk replacers, with constituents including either normally treated (diet B1, calves 1-6) or heat-damaged (diet B2, calves 7-12) skim milk and whey powder. Five healthy calves (1721) fed whole cow's milk served as controls. The calves with diarrhea were euthanized at different stages of the disease when they were 2-5 weeks of age. Further details on the experiments and procedures are given in the other reports (Landsverk 1981a, Landsverk et al. in prep.).

The enzymes studied, incubation times and temperatures were as follows: alkaline prosphatase (EC 3.1.3.1) - 10 and $20 \mathrm{~min}$ at $37^{\circ} \mathrm{C}$; adenosine triphosphate-(ATP)-splitting enzyme $-10 \mathrm{~min}$ at room temperature; acid phosphatase (EC 3.1.3.2) - $45 \mathrm{~min}$ at $37^{\circ} \mathrm{C}$; $\beta$-D-galactosidase (EC 3.2.1.23) $-4 \mathrm{~h}$ at $37^{\circ} \mathrm{C}$; aminopeptidase (EC 3.4.11.2) (with L-alanyl- $\beta$-naphtylamid and L-leucyl$\beta$-naphtylamid as substrate) $-20 \mathrm{~min}$ at room temperature, and non-specific esterase (with $\alpha$-naphtyl acetate as substrate) -15 min at room temperature. Further details on the histochemical methods are given in a previous report (Landsverk 1980). The small intestinal segments examined were: middle duodenum (d2), middle jejunum, and posterior jejunum (pj3). The localization has been described previously (Landsverk 1979, Landsverk 1981a).

\section{RESULTS}

A description of the outbreak and duration of diarrhea, the microbiologic examination, and the gross and microscopic examination of the gastrointestinal tract is given elsewhere 
Thor Landsverk: An Enzyme Histochemical Investigation of the Intestinal Mucosa in Diarrheic Calves

Figu re 1. Alkaline phosphatase, middle duodenum (d2), control calf (21). Normal enzyme reaction with positive villous brush border. No counterstain. $\times 100$.

Fig u re 2. Alkaline phosphatase, middle duodenum (d2), diarrheic calf (1). The staining of the villous brush border is weak and discontinuous. No counterstain. $\times 100$.

F i g u r e 3. ATP-splitting enzyme, posterior jejunum (pj3), control calf (21). Normal enzyme reaction with positive villous brush border. Note the weak staining at the base of the epithelial cells. No counterstain. $\times 100$.

F i g u r e 4. ATP-splitting enzyme, posterior jejunum (pj3), diarrheic calf $(2)$. The villous brush border shows a weak staining. No counterstain. $\times 100$.

F i g u e 5. Acid phosphatase, middle duodenum (d2), control calf (20). Normal enzyme reaction with strong staining of the villous brush border. Note the moderate staining of the supranuclear epithelial cytoplasm (arrows). Some positive cells in the lamina propria are probably macrophages. Weakly counterstained with hematoxylin. $\times 150$.

F i g u r e 6. Acid phosphatase, middle duodenum (d2), diarrheic calf (3). Note the weak reaction in the brush border of villous epitheliai cells and the strong reaction in the supranuclear cytoplasm of these cells (arrows). There are many positive cells, probably macrophages, in the lamina propria. Weakly counterstained with hematoxylin. $\times 150$.

Fig u re 7. Non-specific esterase, middle duodenum (d2), control calf (21). Normal enzyme reaction with strong staining in the supranuclear cytoplasm of the villous epithelial cells. No counterstain. $\times 100$.

F i g u r e 8. Non-specific esterase, middle duodenum (d2), diarrheic calf (1). The cytoplasm of the villous epithelial cell shows a weak staining. No counterstain. $\times 100$. 


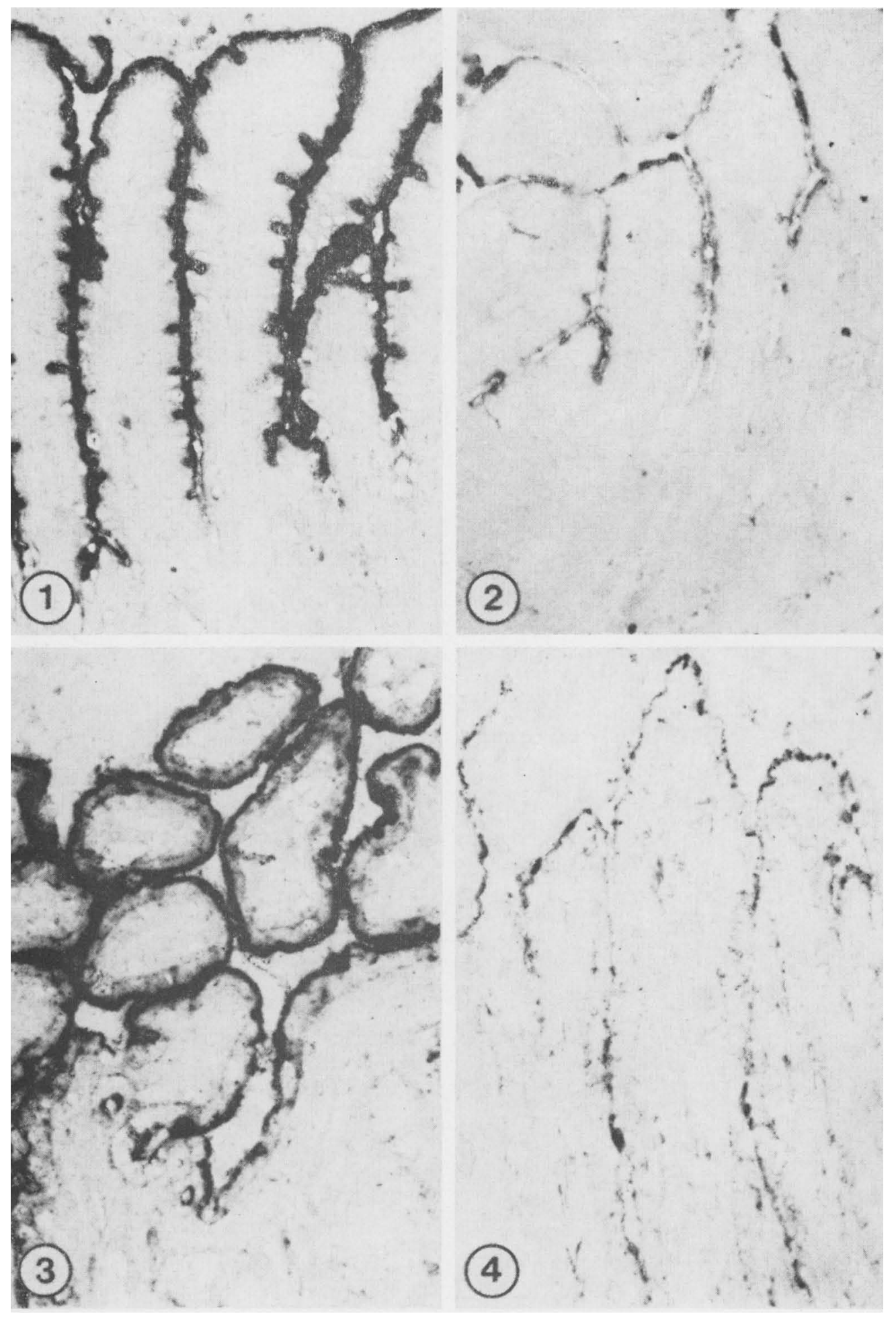



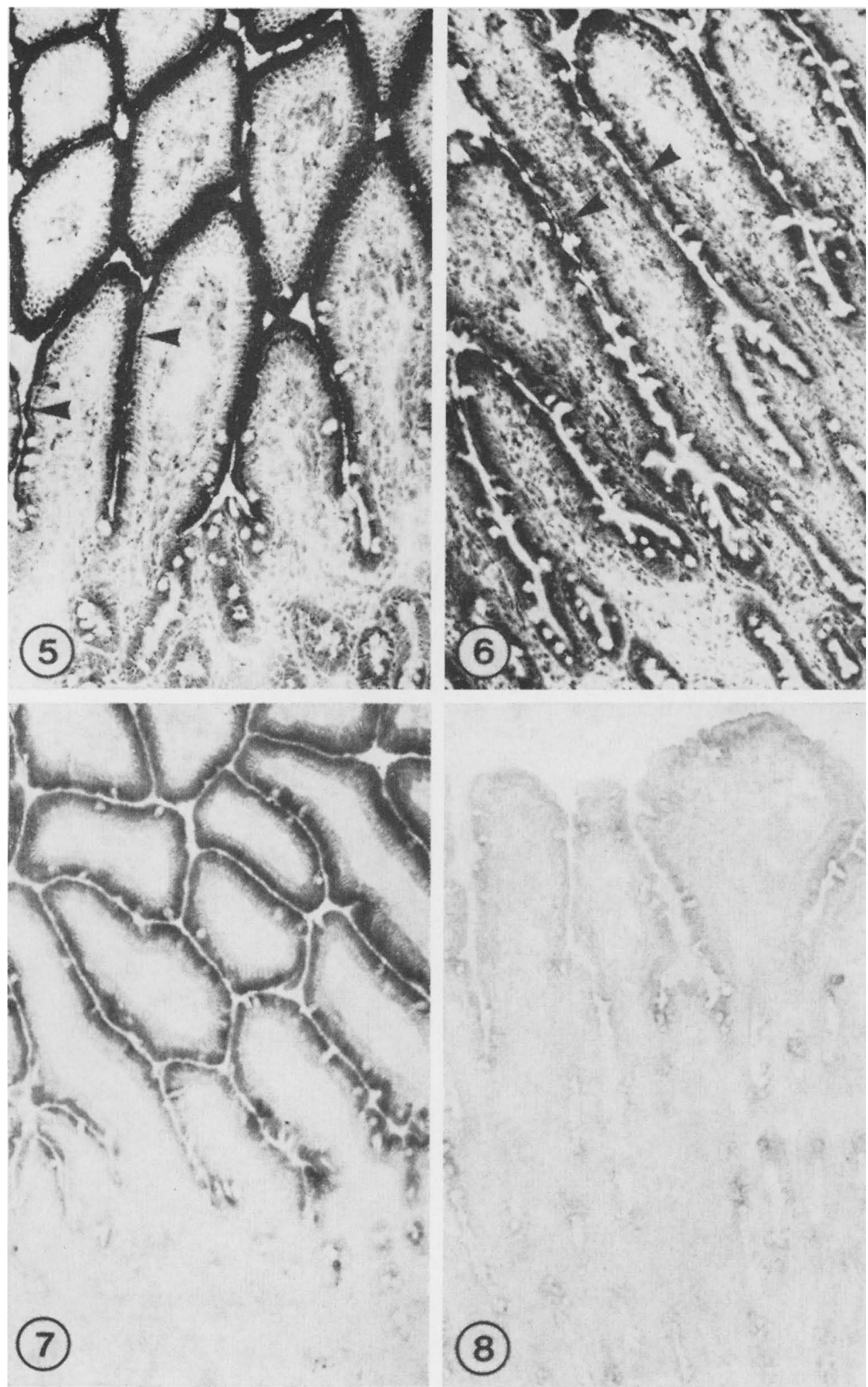
(Landsverk 1981a, b, Landsverk et al. in prep.). For the purposes of the present report a brief statement of the disorder described in the other reports may be given: The diarrhea of calves 1-12 was mainly attributed to the occurrence of intestinal infections. Serologic examinations made a widespread rotavirus infection probable, and studies of frozen sections showed positive immunofluorescence for rotavirus in intestinal villi of calves 1 and 8. Calf 1 showed in addition occurrence of large numbers of Gram negative bacteria, probably Escherichia coli, on the intestinal villi. Calf 9 had large numbers of pseudomonas in the ruminal and intestinal contents. Calves $3,5,11$ and 12 showed a chlamydial infection confined to the posterior small intestine. Some relevant clinical and morphometric data are included in Table 1.

The average regional enzyme reactions in the small intestinal epithelial cells are given in Table 1.

\section{Duodenum}

Convalescents showed no reduction of enzyme reactions. Diarrheic calves showed decrease of several enzymes: alkaline phosphatase (Figs. 1, 2) and the ATP-splitting enzyme of the villous brush border were reduced in 3 calves. The corresponding ATP-splitting enzyme of the crypt was reduced in 6 calves. Acid phosphatase of the villous brush border was reduced in 6 calves (Figs. 5, 6), whereas the cytoplasmic acid phosphatase reaction was either similar or increased as compared with the controls. Three calves showed reduction of the villous brush border $\beta$-Dgalactosidase, while 4 had decrease of the corresponding crypt reaction. Non-specific esterase in the cytoplasm of the villous epithelial cells was reduced in 3 calves (Figs. 7,8 ).

\section{Middle jejunum}

Owing to the random sampling of this area, only the ATPsplitting enzyme was examined. This enzyme had been found to be evenly distributed between the various small intestinal sites in healthy calves (Landsverk 1980). One of the convalescents had a decrease of both the villous and the crypt reaction, and another had a slight decrease of the crypt reaction. Three diarrheic calves displayed decrease of the villous brush border reaction (Figs. 3, 4), whereas these and 2 additional diarrheic calves showed decrease of the corresponding crypt reaction. 


\section{Posterior jejunum and ileum}

ATP-splitting enzyme and aminopeptidase were reduced in 3 calves, 2 of these were diarrheic and one convalescent. The cytoplasmic acid phosphatase reactions were similar to the controls.

\section{DISCUSSION}

The diarrheic condition of the present calves was associated with a decrease in the reaction of several enzymes in the intestinal mucosa. In healthy individuals epithelial cells populating the villi are highly differentiated and equipped with membrane bound enzymes of decisive importance to the absorption of nutrients. The process of epithelial cell proliferation and differentiation occurs in the crypts, the epithelial cells migrating continuously from the crypts to the villi (Lipkin 1973, Sassier \& Bergeron 1978). Enzyme changes during diarrhea may therefore reflect disturbances in the crypt as well as the villous compartment and may be associated with marked structural alterations of the mucosa.

The pathomorphologic changes found in the present calves included villous atrophy and crypt hyperplasia probably resulting from enhanced epithelial cell loss (Landsverk 1981a). Alterations of this kind characterize a wide range of intestinal disorders, in particular viral infections affecting mature villous epithelial cells (Kent \& Moon 1973). One of the best studied of these conditions is transmissible gastroenteritis of pigs (TGE). Prominent enzyme reduction in the villous epithelial cells has been found in TGE (Thake 1968, Hornich et al. 1977). Kinetic studies have revealed a marked acceleration of the migration rate of epithelial cells from the crypt to the villous tips (Thake et al. 1973, Shepherd et al. 1979). It may be that the enhanced migration rate during regenerative hyperplasia does not give the epithelial cells sufficient time to acquire the proper enzyme eqipment. Decrease of membrane bound enzymes in the villi has been found during regenerative hyperplasia after X-ray irradiation (de Both et al. 1974) and in a number of enteric disorders in man characterized by villous atrophy and crypt hyperplasia (Lojda 1974). Interference with epithelial cell maturation may also be a possible cause of the enzyme reduction in the present material; however, not all the results are explained satisfactorily this way. 
In some calves, and particularly among the convalescents, villus to crypt ratios were reduced without any apparent decrease of enzyme reactions. Furthermore, enzyme decrease due to cell immaturity would be expected to affect all enzymes associated with cell maturation to the same degree. In the present material there seemed to be some imbalance between the reduction of the various enzymes. It is probable that a direct destructive effect of microbial agents is an additional cause of decreased enzyme reactions. Rather selective enzyme reduction, particularly of disaccharidases, has been demonstrated in experimental intestinal stasis with bacterial overgrowth and in the absence of apparent changes in the epithelial cell kinetics (Jonas et al. 1977). It is not possible to assess the actual contribution from the microflora precisely with respect to such direct effects in the present material, but it may be suggested that the rotavirus and chlamydial agents demonstrated in some of the calves were of significance. In this material, however, the disaccharidase examined ( $\beta$-D-galactosidase) did not seem particularly vulnerable.

Apparently, brush border acid phosphatase was the enzyme mostly affected in the present material. This acid phosphatase reaction is fluoride-resistant (Landsverk 1980), and it is possible that the enzyme represents the "tail" of an alkaline phosphatase reaction that may persist at this low $\mathrm{pH}(5.0)$ (Connock \& Sturdee 1975). If this is the case, the results for brush border acid phosphatase may reflect general inadequacies of enzyme histochemical methods, i.e. the limitations with regard to quantitative estimates. Thus the applied technique for acid phosphatase may have disclosed minor differences between the calves in the fraction of alkaline phosphatase activity, which are not detectable at $\mathrm{pH}$ optimum.

The decreased enzyme reactions and the villous atrophy with reduction of the intestinal surface area may have contributed to a state of malabsorption in the present calves. Such a state may include insufficient digestion of proteins, carbohydrates, and fats, resulting in excess of available substrate for bacterial fermentation. A malabsorption state may also include disturbances in the transport of electrolytes and water; it is mainly this disorder which is responsible for the clinically recognizable diarrhea (Rowland 1978). The absorption of sodium is especially important in this connection, since transport of this solute 
appears to be closely linked to the absorption of water (Parsons 1967). Sodium absorption in the intestinal epithelium is mediated by the Na-K-ATPase (Charney \& Donowitz 1978), and the Na-KATPase activity is reported to be greater in the villi than in the crypts (Gall et al. 1976). Immaturity of epithelial cells along the villi probably contributes to the decreased ATPase activity and the defective sodium transport in TGE (Kelly et al. 1972, Kerzner et al. 1977). A similar mechanism may have been operating in the present case, though, probably not reflected in the results for the ATP-splitting enzyme, since the Na-K-ATPase is inhibited by the lead in the incubation medium (Jacobsen \& J $\phi r$ gensen 1969). It is probable that the villous portion of the ATPsplitting enzyme includes the activity of alkaline phosphatase as well as nucleoside phosphatase (Landsverk 1980). It is of interest that the crypt reaction, which is distinguished from the villous reaction by its magnesium dependency (Landsverk 1980), was markedly affected in the present calves, indicating an influence of the disorder on nucleoside phosphatase systems.

In conclusion, the intestinal enzyme reduction in the present calves indicates a decreased absorptive capacity of the intestine. It may be of significance that the alterations were mainly confined to the anterior and middle small intestine, where digestive and absorptive processes are most intense. It seems that the posterior regions were not able to compensate this defect.

\section{REFERENCES}

Abel, J. H., R. W. Phillips \& L. D. Lewis: Intestinal mucosae enzymatic and histochemical changes during infectious diarrhea in calves. Amer. J. dig. Dis. 1972, 17, 423-429.

Benz, G. W. \& J. V. Ernst: Alkaline phosphatase activities in intestinal mucosa from calves infected with Cooperia punctata and Eimeria bovis. Amer. J. vet. Res. 1976, 37, 895-900.

Bywater, R. J.\&W. J. Penhale: Depressed lactase activity in the intestinal mucous membrane of calves after neonatal diarrhoea. Res. Vet. Sci. 1969, 10, 591-593.

Charney, A. N. \& M. Donowitz: Functional significance of intestinal $\mathrm{Na}^{+}-\mathrm{K}^{+}-\mathrm{ATPase}$ in vivo ouabain inhibition. Amer. J. Physiol. 1978, 234, E629-E636.

Connock, M. J. \& A. P. Sturdee: Acid hydrolases in the suckling rat small intestine. II. On the importance of alkaline phosphatase inhibition in the histochemical localization of acid phosphatase activity. Histochem. J. 1975, 7, 103-114. 
de Both, N. J., J. M. van Dongen, B. van Hofwegen, J. Keulemans, W. J. Visser \& H. Gaaljard: The influence of various cell kinetic conditions on functional differentiation in the small intestine of the rat. Develop. Biol. 1974, 38, 119-137.

Gall, D. G., D. Chapman, M. Kelly \& J. R. Hamilton: $\mathrm{Na}^{+}$transport in jejunal crypt cells. Gastroenterology 1976, 70, 886. (Abstr.).

Halpin, C. G. \& I. W. Caple: Changes in intestinal structure and function of neonatal calves infected with reovirus-like agent and Escherichia coli. Austr. vet. J. 1976, 52, 438-441.

Hornich, M., E. Salajka \& J. Stěpánek: Malabsorption in newborn piglets with diarrhoeic Escherichia coli infection and transmissible gastro-enteritis. Zbl. Vet. Med. B. 1977, 24, 75-86.

Jacobsen, N. O. \& O. Leth Jørgensen: A quantitative biochemical and histochemical study of the lead method for localization of adenosine triphosphate-hydrolyzing enzymes. J. Histochem. Cytochem. 1969, 17, 443-453.

Jonas, A., P. R. Flanagan \& G. G. Forstner: Pathogenesis of mucosal injury in the blind loop syndrome. Brush border enzyme activity and glycoprotein degradation. J. clin. Invest. 1977, 60, $1321-1330$.

Kelly, M., D. G. Butler \& J. R. Hamilton: Transmissible gastroenteritis in piglets. A model of infantile viral diarrhea. J. Pediatr. 1972, $80,925-931$.

Kent, T. H. \& H. W. Moon: The comparative pathogenesis of some enteric diseases. Based on cases presented at the 22nd annual seminar of the American College of Veterinary Pathologists. Vet. Path. 1973, 10, 414-469.

Kerzner, B., M. H. Kelly, D. G. Gall, D. G. Butler \& J. R. Hamilton: Transmissible gastroenteritis: Sodium transport and the intestinal epithelium during the course of viral enteritis. Gastroenterology 1977, 72, 457-461.

Landsverk, T.: The gastrointestinal mucosa in young milk-fed calves. A scanning electron and light microscopic investigation. Acta vet. scand. $1979,20,572-582$.

Landsverk, T.: Histochemical distribution of enzymes in the small intestine of young milk-fed calves. Acta vet. scand. 1980, 21, $402-414$.

Landsverk, T.: Pathomorphology of the intestinal mucosa in diarrheic calves. Acta vet. scand. 1981a, 22, 435-448.

Landsverk, T.: Peyer's patches and the follicle-associated epithelium in diarrheic calves. Pathomorphology, morphometry and acid phosphatase histochemistry. Acta vet. scand. 1981b, 22, 459471.

Landsverk, $T$. et al.: in prep.

Lipkin, M.: Proliferation and differentiation of gastrointestinal cells. Physiol. Rev. 1973, 53, 891-915.

Lojda, Z.: Cytochemistry of enterocytes and of other cells in the mucous membrane of the small intestine. In: D. H. Smyth: Biomembranes, Vol. 4A, Intestinal Absorption. Plenum Press, London, New York 1974, p. 43-122. 
Parsons, D. S.: Salt and water absorption by the intestinal tract. Brit. med. Bull. 1967, 23, 252-257.

Rowland, H. A. K.: The pathogenesis of diarrhoea. Trans. Roy. Soc. tropic. Med. Hyg. 1978, 72, 289-302.

Sassier, P. \& M. Bergeron: Cellular changes in the small intestine epithelium in the course of cell proliferation and maturation. Subcell. biochem. 1978, 5, 129-185.

Shepherd, R. W., D. G. Butler, E. Cutz, D. G. Gall \& J. R. Hamilton: The mucosal lesion in viral enteritis. Extent and dynamics of the epithelial response to virus invasion in transmissible gastroenteritis of piglets. Gastroenterology 1979, 76, 770-777.

Thake, D. C.: Jejunal epithelium in transmissible gastroenteritis of swine. An electron microscopic and histochemical study. Amer. J. Path. 1968, 53, 149-168.

Thake, D. C., H. W. Moon \& G. Lambert: Epithelial cell dynamics in transmissible gastroenteritis of neonatal pigs. Vet. Path. 1973, $10,330-341$.

\section{SAMMENDRAG \\ En enzym-histokjemisk undersфkelse av tarmmukosa hos kalver med diaré.}

Et utvalg av enzymer i tynntarmsmukosa ble studert hos tolv 2-5 uker gamle kalver, 8 med diaré og 4 rekonvalesenter. Diarékalvene viste reduksjon av enzymene spesielt i duodenum og midtre jejunum; krypt-reaksjonene syntes å være sterkest affisert. I duodenum var alkalisk fosfatase, adenosintrifosfat (ATP)-spaltende enzym og $\beta$-Dgalaktosidase langs villi redusert hos 3 kalver; reaksjonen $i$ de tilsvarende kryptene var nedsatt hos henholdsvis 6 kalver når det gjaldt ATP-spaltende enzym og 4 når det gjaldt $\beta$-D-galaktosidase. Seks kalver viste reduksjon av sur fasfatase $i$ „b $\varnothing$ rstes $\varnothing$ mmen“ av villi og 3 hadde nedgang $i$ reaksjonen av uspesifikk esterase $i$ villi. I midtre jejunum var ATP-spaltende enzym langs villi redusert hos 3 kalver, mens 5 viste nedgang $i$ den tilsvarende krypt-reaksjonen. Rekonvalesentene viste ingen nedgang av enzym-reaksjoner $i$ duodenum, men i midtre og bakre jejunum var det en markert reduksjon av ATPspaltende enzym og aminopeptidase hos én kalv. De nedsatte enzymreaksjoner $i$ dette materialet kan skyldes en mangelfull differensiering av epitelcellene forbundet med regenerativ hyperplasi $i$ kryptene og/eller mikrobiell destruksjon av enzymene.

(Received July 20, 1981).

Reprints may be requested from: T. Landsverk, the Department of Pathology, Veterinary College of Norway, P.O. Box 8146, Dep., Oslo 1, Norway. 